\title{
Dichlorophenarsine Hydrochloride
}

National Cancer Institute

\section{Source}

National Cancer Institute. Dichlorophenarsine Hydrochloride. NCI Thesaurus. Code C75248.

A hydrochloride salt form of dichlorophenarsine, an arsenic-containing agent formerly used in the treatment of syphilis. 